\title{
MORPHOPHYSIOLOGICAL AND PRODUCTIVE RESPONSES OF SUNFLOWER VARIETIES TO IRRIGATION ${ }^{1}$
}

\author{
WELSON LIMA SIMÕES ${ }^{2}$, MARCOS ANTONIO DRUMOND² ${ }^{2}$ ANDERSON RAMOS DE OLIVEIRA², SÉRGIO LUIZ \\ GONÇALVES $^{3}$, MIGUEL JULIO MACHADO GUIMARÃES $^{4 *}$
}

\begin{abstract}
The high luminosity rates and high annual average temperatures of the Brazilian semiarid region, combined with the use of irrigation and adaptability of the sunflower crop to local climate, favor increased achene yield due to acceleration of morphophysiological processes. The objective of this work was to evaluate the morphophysiological and productive characteristics of sunflower varieties grown under drip irrigation in the Sub-Mid São Francisco River Valley. The experiment was conducted in the Experimental Field of the Brazilian Agricultural Research Corporation (Embrapa Semiarid), in Petrolina, State of Pernambuco, Brazil, in a randomized block design, with 21 sunflower varieties and four replications. The variables evaluated were flowering time, plant height, number of live leaves, stem and capitulum diameter, number of lodged and broken plants, stem curvature, relative chlorophyll index, photosynthesis, stomatal conductance, transpiration, average leaf temperature, 1000-achene weight and achene yield of the sunflower varieties. The treatments presented flowering time of 43 to 59 days after sowing, plant height of 1.0 to $1.4 \mathrm{~m}$, capitulum diameter of 0.154 to $0.221 \mathrm{~m}$, chlorophyll content of 30.8 to $33.98 \mathrm{Spad}$ units and 1000 -achene weight of 35.61 to $80.30 \mathrm{~g}$. The sunflower varieties V7 and V8 stood out, with achene yields above 2,960 kg ha ${ }^{-1}$ and low number of lodged and broken plants, indicating a greater adaptability irrigation crops in the Sub-Mid São Francisco River Valley.
\end{abstract}

Keywords: Helianthus annuus L.. Physiology. Biometry. Agronomic performance.

\section{RESPOSTAS MORFOFISIOLÓGICAS E PRODUTIVAS DE VARIEDADES DE GIRASSOL IRRIGADAS}

\begin{abstract}
RESUMO - As altas taxas de luminosidade e elevadas temperaturas médias anuais da região semiárida do Brasil, associadas ao uso de irrigação e à adaptabilidade da cultura do girassol ao clima local podem favorecer o aumento da produtividade, devido à aceleração dos seus processos morfofísiológicos. Assim, objetivou-se avaliar o desempenho morfofisiológico e produtivo de variedades de girassol, sob cultivo irrigado por gotejamento, no Submédio São Francisco. O experimento foi desenvolvido no Campo Experimental da Embrapa Semiárido, em Petrolina, PE, em delineamento de blocos casualizados, sendo os tratamentos representados por 21 variedades de girassol, com quatro repetições. As variáveis analisadas foram: período de floração, altura, número de folhas, diâmetro do caule e do capítulo, número de plantas acamadas e quebradas, curvatura do caule, índice relativo de clorofila, fotossíntese, condutância estomática, transpiração, temperatura média foliar, peso de 1000 aquênios e produtividade das variedades de girassol. Verificou-se que o tempo de floração varia de 43 a 59 dias após o plantio, a altura das plantas de 1,0 a 1,4 m, o diâmetro dos capítulos de 0,154 a 0,221 m, o teor de clorofila de 30,8 a 33,98 e o peso de 1000 aquênios de 35,61 a 80,30 g nas variedades de girassol avaliadas. As variedades V7 e V8 se destacam por apresentarem produtividade acima de $2.960 \mathrm{~kg}$ de aquênios por hectare e baixo número de plantas acamadas e quebradas, indicando maior adaptabilidade ao cultivo irrigado na região do Submédio São Francisco.
\end{abstract}

Palavras-Chaves: Helianthus annuus L.. Fisiologia. Biometria. Desempenho agronômico.

\footnotetext{
* Corresponding author

${ }^{1}$ Received for publication in 07/25/2016; accepted in 02/03/2017.

${ }^{2}$ Embrapa Semiárido, Petrolina, PE, Brazil; welson.simoes@embrapa.br, marcos.drumond@embrapa.br, anderson.oliveira@embrapa.br.

${ }^{3}$ Embrapa Soja, Londrina, PR, Brazil; sergio.goncalves@embrapa.br.

${ }^{4}$ Department of Agricultural Engineering, Universidade Federal Rural de Pernambuco, Recife, PE, Brazil; mjmguimaraes@hotmail.com.
} 


\section{INTRODUCTION}

Sunflower (Helianthus annuus L., Asteraceae) is indigenous to the southwest of Mexico. This species is among the five main world oil producing species (NOBRE et al., 2010) due to its desirable characteristics from the agricultural and economic point of view (SILVA et al., 2013). Sunflower is grown in all continents, with estimated world production of 39.5 million $\mathrm{Mg}$ in the 2015/2016 crop season. According to CONAB (2016), in this crop season, the largest world producers of sunflower were Ukraine (11 million $\mathrm{Mg}$ ), Russia (9.7 million $\mathrm{Mg}$ ), the European Union (8 million $\mathrm{Mg}$ ) and Argentina (2.7 million $\mathrm{Mg}$ ). The annual Brazilian production of sunflower is approximately $180,000 \mathrm{Mg}$, which is mostly from the States of Mato Grosso $(139,000 \mathrm{Mg})$, Minas Gerais $(21,200 \mathrm{Mg})$ and Goiás $(12,200 \mathrm{Mg})$.

The socioeconomic importance of sunflower is due to its multiple uses. It can be used as human food, since the oil of its seeds has a desirable composition as a source of nutrients and vitamins (GRILO et al., 2014), as raw material for biodiesel production (FERRARI; SOUZA, 2009; HARRIS et al., 2016) and as feed for animals (OLIVEIRA et al., 2015).

Various technologies have been developed for sunflower crops. The choice of varieties is one of the main factors that must be considered in the initial phase of implementation of a sunflower crop. Due to the interaction between genotypes and environments, continuous evaluations are necessary in order to determine the agronomic performance of the genotypes and their adaptation to different local conditions (PORTO; CARVALHO; PINTO, 2007).

Most researches for selection of crop varieties for a particular location consider several important parameters to assess their agricultural potential, such as the crop yield, plant growth (phytomass accumulation) or primary process of $\mathrm{CO}_{2}$ assimilation, transpiration rate, water potential in the plant, growth rate and stomatal opening (ZHENG et al., 2011; SHARMA et al., 2015).

The viability of sunflower crops in the Brazilian semiarid region, which has high luminosity rates and high annual average temperatures, is directly related to the selection of adapted varieties to the region and good irrigation management. Thus, crop efficiency is related to the balance between the water, soil, plant and atmosphere components, aiming to optimize the morphophysiological processes of the plant and increase the yield. Thus, the objective of this work was to evaluate the morphophysiological and productive characteristics of sunflower varieties grown under drip irrigation in the Sub-Mid São Francisco River Valley.

\section{MATERIAL E METHODS}

The experiment was carried out in the Experimental Field of the Brazilian Agricultural Research Corporation (Embrapa Semiarid), Petrolina, State of Pernambuco, Brazil $\left(9^{\circ} 09^{\prime} \mathrm{S}\right.$, $40^{\circ} 22^{\prime} \mathrm{W}$ and altitude of $365.5 \mathrm{~m}$ ). The climate of the region is BSWh, tropical semiarid, according to the Köppen classification, with a rainy season (November to April) and annual average precipitation bellow $800 \mathrm{~mm}$ and irregularly distributed. The local annual average temperature ranges from $23^{\circ}$ to $27^{\circ} \mathrm{C}$, with annual evaporation of approximately $2,000 \mathrm{~mm}$, annual relative humidity of approximately $50 \%$, and annual average solar incidence of 2,800 hours (MOURA et al., 2007).

A randomized block experimental design with four replications was used. Treatments consisted of 21 varieties and hybrids of sunflower (Table 1). The plots consisted of six 6.0 -m rows, spaced $0.7 \mathrm{~m}$ apart with plants spaced $0.3 \mathrm{~m}$ apart.

Table 1. Varieties and hybrids of sunflower evaluated in the experimental field of the Brazilian Agricultural Research Corporation (Embrapa Semiárido).

\begin{tabular}{|c|c|c|c|c|c|}
\hline Identification & Variety & Identification & Variety & Identification & Variety \\
\hline V1 & BRS G26 & V8 & AGUARÁ 06 & V15 & PARAISO 22 \\
\hline $\mathrm{V} 2$ & BRS 321 & V9 & OLISUN & V16 & PARAISO 33 \\
\hline V3 & BRS 322 & V10 & M734 & V17 & PARAISO 65 \\
\hline V4 & BRS 323 & V11 & NTO 3.0 & V18 & HÉLIO 251 \\
\hline V5 & BRS 324 & V12 & NTO 2.0 & V19 & HÉLIO 863 \\
\hline V6 & EMBRAPA 122 & V13 & CATISSOL & V20 & HÉLIO 253 \\
\hline V7 & AGUARÁ 04 & V14 & MULTISSOL & V21 & HÉLIO 360 \\
\hline
\end{tabular}

The soil of the experimental area was classified as Entisol (73\% sand, 19\% silt and 8\% clay). The results of the soil chemical analysis are presented in Table 2. These results were used to determine the macro and micronutrients for sowing fertilization and topdressing, which were carried out according to the recommendations for the crop. 
Table 2. Soil chemical analysis of the experimental area. Experimental field of the Brazilian Agricultural Research Corporation (Embrapa Semiárido).

\begin{tabular}{|c|c|c|c|c|c|c|c|c|c|c|c|c|c|c|c|c|}
\hline$\overline{\mathrm{OM}}$ & $\mathrm{pH}$ & $\mathrm{EC}$ & $\mathrm{K}$ & $\mathrm{Ca}$ & $\mathrm{Mg}$ & $\mathrm{Na}$ & $\mathrm{Al}$ & $\mathrm{H}+\mathrm{Al}$ & SB & CEC & $\overline{\mathrm{V}}$ & $\bar{P}$ & $\mathrm{Cu}$ & $\mathrm{Fe}$ & $\mathrm{Mn}$ & $\mathrm{Zn}$ \\
\hline $\mathrm{g} \mathrm{kg}^{-1}$ & & $\mathrm{dS} \mathrm{m}^{-1}$ & & & & & $\mathrm{dm}$ & & & & $\%$ & & & $\mathrm{ng} \mathrm{dm}$ & & \\
\hline 02 & 4.8 & 0.6 & 0.28 & 1.4 & 0.4 & 0.04 & 0.05 & 1.48 & 2.12 & 3.6 & 59 & 4.2 & 0.2 & 9.1 & 12 & 1.1 \\
\hline
\end{tabular}

$\mathrm{OM}=$ organic matter; $\mathrm{EC}=$ electric conductivity; $\mathrm{SB}=$ sum of exchangeable bases; $\mathrm{CEC}=$ effective cation exchange capacity; $\mathrm{V}=$ base saturation index.

Sowing fertilization was carried out manually, using a hoe to place the fertilizer to a depth of $15 \mathrm{~cm}$, with application of $30 \mathrm{~kg} \mathrm{ha}^{-1}$ of $\mathrm{P}_{2} \mathrm{O}_{5}$, (simple superphosphate). $\mathrm{N}$ (40 $\left.\mathrm{kg} \mathrm{ha}^{-1}\right)$, $\mathrm{K}\left(40 \mathrm{~kg} \mathrm{ha}^{-1}\right), \mathrm{S}\left(20 \mathrm{~kg} \mathrm{ha}^{-1}\right)$ and B $\left(1 \mathrm{~kg} \mathrm{ha}^{-1}\right)$ were applied as topdressing, using urea, potassium chloride, magnesium sulfate and boric acid, respectively. Liming was carried out 60 days before sowing, as recommended by Castro and Oliveira (2005).

Irrigation was carried out with a drip irrigation system, using drippers spacing of $0.30 \mathrm{~m}$ and flow of $2.4 \mathrm{~L} \mathrm{~h}^{-1}$, forming a continuous wet strip along the plant rows. Water from the São Francisco River was used for irrigation, which had electrical conductivity of $0.06 \mathrm{dS} \mathrm{m} \mathrm{m}^{-1}$ and $\mathrm{pH}$ of 7.6. Irrigations were carried out each other day, based on the crop evapotranspiration, with reference evapotranspiration (ETo) obtained from a meteorological station installed near the experimental area, using the Penman-Monteith method and the crop coefficient proposed by Allen et al. (2006), which is recommended for sunflower crops in the region. The irrigation ended for subsequent harvesting of the crop when the seeds reached the physiological maturation stage.

The plot evaluated area consisted of the four central meters of the two central plant rows. The characteristics evaluated were flowering time (days from sowing to flowering), plant height, number of live leaves (at flowering), stem diameter, capitulum diameter, number of lodged and broken plants, stem curvature (at the physiological maturation stage), relative chlorophyll index (at the leaf physiologically maturity stage), 1000-achenes weight and achene yield.

The relative chlorophyll index was evaluated in the $5^{\text {th }}$ or $6^{\text {th }}$ leaf below the capitulum that was exposed to the sun, in a chlorophyll meter SPAD-502 (Minolta Corporation, Ramsey, USA). The stem curvature was evaluated using a scale of visual grades $(1=$ inclined, $2=$ vertical, $3=$ semi-inverted with erect base, $4=$ semi-inverted with curved base, $5=$ vertical with erect base, $6=$ inverted with curved base and $7=$ reflex (VOGT; BALBINOT JÚNIOR; SOUZA, 2010).

The physiological characteristics of the varieties were monitored. The stomatal conductance, leaf average temperature, leaf transpiration and photosynthesis of selected physiologically mature leaves were evaluated during the flowering stage, using an infrared gas analyzer (IRGA, LI-6400XT) with radiation of $1,500 \mu \mathrm{mol} \mathrm{m} \mathrm{m}^{-2} \mathrm{~s}^{-1}$. Readings were performed from 9:00 to 12:00 h, on non-cloudy days to avoid instabilities caused by rapid variations of solar radiation. Climatic data from a meteorological station installed near the experimental area were used to assess the average air temperature $\left(23^{\circ} \mathrm{C}\right)$, relative air humidity $(68.9 \%)$, total radiation $(17.8 \mathrm{MJ})$ and wind speed $\left(1.28 \mathrm{~m} \mathrm{~s}^{-1}\right)$ during the crop cycle.

The means of the variables were subjected to the Scott-Knott test at 5\% probability. Statistical analyzes were carried out in the program Sisvar (FERREIRA, 2014)

\section{RESULTS AND DISCUSSION}

The days from sowing to flowering (DSF), plant height, number of live leaves (NLL), capitulum and stem diameter, lodged and broken plants and stem curvature of the varieties showed significant differences (Table 3 ) by the $\mathrm{F}$ test at $5 \%$ of probability.

The varieties V2 and V6 had early flowering, with 43 and 44 DSF, respectively, whereas the varieties V3, V7, V9, V10, V11, V12, V15, V17 and V18 had late flowering (54 to 59 DSF) and did not differ statistically. The differences in flowering periods were mainly due to the differences between cultivars, however, they may be related to the climatic conditions of semiarid region (Northeast), where temperatures are higher than the Brazilian South, Southeast and Central-West. The DSF results were lower than those found by Andrade et al. (2011) (65 days) in 10 varieties of sunflower in Souza, State of Paraíba (PB), Brazil, including the variety Paraíso 22. Farias Neto et al. (2000) studied the variety V10 grown in the Cerrado biome in the Distrito Federal, Brazil, and found initial flowering at 64 days after emergence (DAE) in rainfed and at 69 DAE in irrigated crops. Backes et al. (2008) studied sunflower genotypes at different sowing times and found average initial flowering at 61.5 days for the hybrids $\mathrm{H} 250, \mathrm{H} 251, \mathrm{H} 358$ and $\mathrm{H} 360$, in the State of Santa Catarina. On the other hand, Capone et al. (2012) found average initial flowering at 54.1 days. According to Castro and Farias (2005), low temperatures, low luminosity and high humidity prolong the crop cycle, delaying flowering and physiological maturation. 
Table 3. Days from sowing to flowering (DSF), plant height (PH), number of live leaves (NLL), stem diameter (SD), capitulum diameter (CD), number of lodged (NLP) and broken (NBP) plants and stem curvature (SC) of sunflower varieties. Brazilian Agricultural Research Corporation (Embrapa Semiárido).

\begin{tabular}{|c|c|c|c|c|c|c|c|c|}
\hline Variety & DSF & $\mathrm{PH}(\mathrm{m})$ & NLL & $\mathrm{SD}(\mathrm{mm})$ & $\mathrm{CD}(\mathrm{cm})$ & NLP & $\mathrm{NBP}$ & $\mathrm{SC}$ \\
\hline V1 & $51 \mathrm{~b}$ & $1.3 \mathrm{a}$ & $29.1 \mathrm{a}$ & $15.8 \mathrm{~b}$ & $19.3 \mathrm{c}$ & $1.3 \mathrm{~b}$ & $0.00 \mathrm{~b}$ & $5.0 \mathrm{a}$ \\
\hline $\mathrm{V} 2$ & $43 c$ & $1.0 \mathrm{~b}$ & $24.9 \mathrm{~b}$ & $11.4 \mathrm{~b}$ & $17.1 \mathrm{~d}$ & $7.0 \mathrm{a}$ & $0.50 \mathrm{~b}$ & $5.0 \mathrm{a}$ \\
\hline V4 & $48 \mathrm{~b}$ & $1.1 \mathrm{~b}$ & $24.5 \mathrm{~b}$ & $15.2 \mathrm{~b}$ & $15.4 \mathrm{~d}$ & $4.5 \mathrm{a}$ & $0.25 \mathrm{~b}$ & $6.0 \mathrm{a}$ \\
\hline V5 & $49 \mathrm{~b}$ & $1.0 \mathrm{~b}$ & $22.8 \mathrm{~b}$ & $13.3 \mathrm{~b}$ & $17.3 \mathrm{~d}$ & $3.3 \mathrm{a}$ & $4.75 \mathrm{a}$ & $5.3 \mathrm{a}$ \\
\hline V6 & $44 \mathrm{c}$ & $1.2 \mathrm{a}$ & $25.6 \mathrm{~b}$ & $17.8 \mathrm{a}$ & $18.3 \mathrm{c}$ & $3.0 \mathrm{a}$ & $1.50 \mathrm{~b}$ & $5.0 \mathrm{a}$ \\
\hline V8 & $59 a$ & $1.3 \mathrm{a}$ & $26.5 \mathrm{a}$ & $19.0 \mathrm{a}$ & $21.3 \mathrm{a}$ & $0.5 \mathrm{~b}$ & $0.50 \mathrm{~b}$ & $4.7 \mathrm{~b}$ \\
\hline V9 & $55 \mathrm{a}$ & $1.4 \mathrm{a}$ & $25.0 \mathrm{~b}$ & $17.0 \mathrm{a}$ & $22.1 \mathrm{a}$ & $0.3 \mathrm{~b}$ & $2.00 \mathrm{~b}$ & $4.3 \mathrm{~b}$ \\
\hline V10 & $54 \mathrm{a}$ & $1.1 \mathrm{~b}$ & $22.9 \mathrm{~b}$ & $15.3 \mathrm{~b}$ & $17.8 \mathrm{~d}$ & $0.8 \mathrm{~b}$ & $2.75 \mathrm{a}$ & $5.3 \mathrm{a}$ \\
\hline V11 & $57 \mathrm{a}$ & $1.3 \mathrm{a}$ & $27.0 \mathrm{a}$ & $17.6 \mathrm{a}$ & $19.1 \mathrm{c}$ & $2.3 \mathrm{~b}$ & $2.00 \mathrm{~b}$ & $5.0 \mathrm{a}$ \\
\hline V12 & $55 \mathrm{a}$ & $1.2 \mathrm{a}$ & $27.0 \mathrm{a}$ & $17.8 \mathrm{a}$ & $18.7 \mathrm{c}$ & $2.8 \mathrm{a}$ & $5.00 \mathrm{a}$ & $4.7 \mathrm{~b}$ \\
\hline V17 & $54 \mathrm{a}$ & $1.1 \mathrm{~b}$ & $26.1 \mathrm{a}$ & $22.6 \mathrm{a}$ & $21.6 \mathrm{a}$ & $0.8 \mathrm{~b}$ & $1.50 \mathrm{~b}$ & $4.7 \mathrm{~b}$ \\
\hline V18 & $54 \mathrm{a}$ & $1.3 \mathrm{a}$ & $31.1 \mathrm{a}$ & $21.8 \mathrm{a}$ & $19.9 \mathrm{~b}$ & $1.0 \mathrm{~b}$ & $0.75 \mathrm{~b}$ & $5.3 \mathrm{a}$ \\
\hline V19 & $50 \mathrm{~b}$ & $1.0 \mathrm{~b}$ & $24.4 \mathrm{~b}$ & $17.0 \mathrm{a}$ & $20.3 \mathrm{~b}$ & $2.0 \mathrm{~b}$ & $0.50 \mathrm{~b}$ & $5.3 \mathrm{a}$ \\
\hline V20 & $50 \mathrm{~b}$ & $1.1 \mathrm{~b}$ & $23.6 \mathrm{~b}$ & $16.9 \mathrm{a}$ & $19.9 b$ & $1.5 \mathrm{~b}$ & $3.50 \mathrm{a}$ & $4.3 \mathrm{~b}$ \\
\hline V21 & $51 \mathrm{~b}$ & $1.1 \mathrm{~b}$ & $24.4 \mathrm{~b}$ & $14.9 \mathrm{~b}$ & $20.3 \mathrm{~b}$ & $3.5 \mathrm{a}$ & $2.50 \mathrm{~b}$ & $5.3 \mathrm{a}$ \\
\hline $\mathrm{CV}(\%)$ & 4.62 & 9.59 & 9.64 & 15.61 & 11.28 & 76.25 & 96.51 & 7.70 \\
\hline
\end{tabular}

$\mathrm{CV}=$ coefficient of variation. Means followed by the same letter in the column did not differ by the Scott-Knott test at $5 \%$ probability.

The average plant height $(\mathrm{PH})$ of the varieties formed two groups, the first with heights of 1.0 to $1.1 \mathrm{~m}$ and the second with heights from 1.2 to $1.4 \mathrm{~m}$. These values are within the limits indicated for commercial varieties of sunflower $(0.7$ to $4.0 \mathrm{~m})$ (CASTRO; FARIAS, 2005). The differences in PH were due to the genetic characteristics of each cultivar and their adaptation to their local climatic conditions. The variety V10, grown in the Cerrado biome, reached a $\mathrm{PH}$ of $1.58 \mathrm{~m}$ in rainfed and $2.01 \mathrm{~m}$ in irrigated conditions (FARIAS NETO et al., 2000). Silva et al. (2007) evaluate the sunflower PH and found a relative increase in water availability, with increases of 1.48 and $1.51 \mathrm{~m}$ with irrigation water depths of 100 and $130 \%$ of crop evapotranspiration, respectively. Nobre et al. (2010) studied the variety Embrapa 122-V2000 under different irrigation water depths with a domestic effluent and found a maximum $\mathrm{PH}$ of $1.59 \mathrm{~m}$.

The varieties V1, V3, V7, V8, V11, V12, V13, V15, V17 and V18 formed a group with number of live leaves at flowering (NLL) of 26.1 to 31.1, which were statistically higher than the NLL of other varieties (Table 3). Despite these differences, the NLL of all cultivars were within those indicated by Castro and Farias (2005) (20 to 40 leaves). According to these authors, the sunflower leaves have heliotropism, facilitating the capture of solar rays. The differences in NLL were also due to the characteristics of each cultivar and local climatic conditions, especially temperature. A high number of leaves is desirable, since the leaf is responsible for the photosynthetic process, whose product will be translocated to vegetative organs during the plant growth and reproductive organs. The adaptation of the cultivar to high temperatures, such as those in the Brazilian semiarid, may result in different in number of leaves, since according to Ferreira (2007), the total number of leaves in high-temperature environments is determined by the balance between two condition, the first is the increase in number of leaves due to a high production rate, and the second is the decrease in number of leaves due to the short leaf production period.

The stem diameter (SD) is the parameter that defines the capacity of the plant to bear the capitulum and the resistance to lodging (BISCARO et al., 2008). The SD of the varieties V1, V2, V4, V5, V10, V13, V14 and V21 formed a group with average of $14.23 \mathrm{~mm}$, which was statistically lower than the second group formed, whose average was $18.28 \mathrm{~mm}$. The formation of different clusters according to the SD is related to the genetic characteristics of the cultivars, which are determined by their genetic inheritance and adaptation to local edaphoclimatic conditions. The stem diameter of the sunflower cultivars has great amplitude, which can vary from 10 to $80 \mathrm{~mm}$ (CASTRO; FARIAS, 2005). Gomes et al. (2012) found SD of 15.9 to $22.7 \mathrm{~mm}$ in irrigated crops, whereas Backes et al. (2008) found $\mathrm{SD}$ of 24.4 (Embrapa 122), 22.0 (Catissol), 24.5 (Hélio 251), 27.9 (Hélio 360) and $24.3 \mathrm{~mm}$ (Aguará 4) in rainfed crops, but with regular distribution of rain; these SD were greater than those 
found in the present work for the same cultivars.

The capitulum diameter (CD) of the varieties had great statistical variability. The varieties V8, V9, V15 and V17 formed a group with the largest diameters $(21.1$ to $22.1 \mathrm{~cm})$, followed by the V18, V19, V20 and V21 (19.9 to $20.3 \mathrm{~cm})$. The varieties $\mathrm{V} 2, \mathrm{~V} 3, \mathrm{~V} 4, \mathrm{~V} 5, \mathrm{~V} 10$ and V14 formed a group with the lowest CD (15.4 to $17.9 \mathrm{~cm})$. These results confirm those found by Farias Neto et al. (2000), who found $\mathrm{CD}$ of $17.2 \mathrm{~cm}$ for the variety $\mathrm{V} 10$ in irrigated crops in the Cerrado biome.

The number of lodged plants (NLP) of the varieties showed significant differences. The varieties V2, V3, V4, V5, V6, V12, V13, V14 and V21 showed the highest NLP, which may be related to the stem diameter, since cultivars V2, V4, V5, V13, V14 and V21 also had small stem diameters, which decrease lodging resistance. The number of broken plants (NBP) of the varieties also showed significant differences. The varieties V12, V5, V20 and V10 showed the highest NBP. Lodged or broken plants are not desirable in mechanized harvesting systems, since they represent yield losses, once these plants are not harvested and may hinder the harvesting (ANDRADE et al., 2011).

The variety V15 showed the lowest grade of stem curvature (SC) (3.3), followed by the V20, V16 and V9 (4.3) and V12, V17 and V8 (4.7). Most cultivars have intermediate SC, which is a desirable characteristic, since the capitula are not completely erect, which would make them more susceptible to bird attacks (BORGES; LUCAS; PAES, 2013) and not fully inclined, which would hinder the harvesting. The cultivar V15 was the most erect (SC of 3.3), thus, it would tend to show achene yield loss due to bird attacks. The varieties V7 and V8 stood out, with low number of lodged and broken plants, which facilitates the harvesting process.

The physiological and productive characteristics of the cultivars (Table 4) showed significant differences. The cultivars were grouped in two classes as a function of the relative chlorophyll index (CL). The the cultivars V1, V5, $\mathrm{V} 8, \mathrm{~V} 13, \mathrm{~V} 14, \mathrm{~V} 15, \mathrm{~V} 18, \mathrm{~V} 19, \mathrm{~V} 20$ and V21 had the highest CL, however, the highest CL did not directly represent highest photosynthetic rates. This result may be related to the adaptation of these varieties to the local climatic conditions, especially solar radiation and temperature. The $\mathrm{CL}$ is used as an indicator of physiological changes in response to the environment, helping to differentiate cultivars with greater photoassimilate potential and greater development due to their adaptation to different environments (REGO; POSSAMAI, 2006).

Table 4. Relative chlorophyll index (CL), photosynthetic rate (PR), stomatal conductance (STC), transpiration (TR), leaf average temperature (LAT), 1000-achene weight (1000AW) and achene yield (AY) of sunflower varieties. Brazilian Agricultural Research Corporation (Embrapa Semiárido).

\begin{tabular}{cccccccc}
\hline Variety & $\begin{array}{c}\mathrm{CL} \\
\text { Spad } \\
\text { units }\end{array}$ & $\begin{array}{c}\mathrm{PR} \\
\mu \mathrm{mol} \mathrm{CO} \mathrm{C} \mathrm{m}^{-2} \mathrm{~s}^{-1}\end{array}$ & $\begin{array}{c}\mathrm{STC} \\
\mathrm{mol} \mathrm{H}_{2} \mathrm{O} \mathrm{m}^{-2} \mathrm{~s}^{-1}\end{array}$ & $\begin{array}{c}\mathrm{TR} \\
\mathrm{mmol} \mathrm{H}_{2} \mathrm{O} \mathrm{m}^{-2} \mathrm{~s}^{-1}\end{array}$ & $\begin{array}{c}\mathrm{LAT} \\
{ }^{\circ} \mathrm{C}\end{array}$ & $\begin{array}{c}1000 \mathrm{AW} \\
\mathrm{g}\end{array}$ & $\begin{array}{c}\text { AY } \\
\mathrm{kg} \mathrm{ha}^{-1}\end{array}$ \\
\hline V1 & $34.00 \mathrm{a}$ & $13.50 \mathrm{~b}$ & $0.380 \mathrm{a}$ & $10.433 \mathrm{a}$ & $39.44 \mathrm{a}$ & $76.75 \mathrm{a}$ & $2,361.07 \mathrm{~b}$ \\
V2 & $30.85 \mathrm{~b}$ & $6.47 \mathrm{c}$ & $0.209 \mathrm{~b}$ & $7.747 \mathrm{~b}$ & $40.34 \mathrm{a}$ & $70.50 \mathrm{a}$ & $1,604.27 \mathrm{~d}$ \\
V3 & $32.07 \mathrm{~b}$ & $11.83 \mathrm{~b}$ & $0.297 \mathrm{~b}$ & $10.637 \mathrm{a}$ & $38.70 \mathrm{~b}$ & $61.00 \mathrm{~b}$ & $2,215.35 \mathrm{c}$ \\
V4 & $31.15 \mathrm{~b}$ & $12.20 \mathrm{~b}$ & $0.331 \mathrm{~b}$ & $9.750 \mathrm{a}$ & $39.43 \mathrm{a}$ & $66.25 \mathrm{~b}$ & $2,254.65 \mathrm{c}$ \\
V5 & $33.72 \mathrm{a}$ & $12.29 \mathrm{~b}$ & $0.331 \mathrm{~b}$ & $9.573 \mathrm{a}$ & $39.60 \mathrm{a}$ & $73.75 \mathrm{~b}$ & $1,921.80 \mathrm{c}$ \\
V6 & $32.02 \mathrm{~b}$ & $9.03 \mathrm{c}$ & $0.197 \mathrm{~b}$ & $7.813 \mathrm{~b}$ & $40.55 \mathrm{a}$ & $74.75 \mathrm{a}$ & $1,262.85 \mathrm{~d}$ \\
V7 & $31.75 \mathrm{~b}$ & $16.70 \mathrm{a}$ & $0.357 \mathrm{~b}$ & $8.400 \mathrm{~b}$ & $38.78 \mathrm{~b}$ & $59.25 \mathrm{~b}$ & $3,105.00 \mathrm{a}$ \\
V8 & $33.32 \mathrm{a}$ & $16.87 \mathrm{a}$ & $0.387 \mathrm{a}$ & $9.253 \mathrm{~b}$ & $39.15 \mathrm{a}$ & $58.00 \mathrm{~b}$ & $2,962.82 \mathrm{a}$ \\
V9 & $31.25 \mathrm{~b}$ & $17.30 \mathrm{a}$ & $0.491 \mathrm{a}$ & $10.833 \mathrm{a}$ & $38.12 \mathrm{~b}$ & $68.25 \mathrm{a}$ & $2,421.05 \mathrm{~b}$ \\
V10 & $31.05 \mathrm{~b}$ & $12.73 \mathrm{~b}$ & $0.427 \mathrm{a}$ & $10.667 \mathrm{a}$ & $38.98 \mathrm{~b}$ & $80.25 \mathrm{a}$ & $2,188.92 \mathrm{c}$ \\
V11 & $32.30 \mathrm{~b}$ & $14.53 \mathrm{a}$ & $0.414 \mathrm{a}$ & $9.603 \mathrm{a}$ & $39.52 \mathrm{a}$ & $66.25 \mathrm{~b}$ & $2,490.37 \mathrm{~b}$ \\
V12 & $32.62 \mathrm{~b}$ & $18.93 \mathrm{a}$ & $0.559 \mathrm{a}$ & $11.900 \mathrm{a}$ & $38.06 \mathrm{~b}$ & $62.50 \mathrm{~b}$ & $3,075.00 \mathrm{a}$ \\
V13 & $33.07 \mathrm{a}$ & $16.10 \mathrm{a}$ & $0.388 \mathrm{a}$ & $9.700 \mathrm{a}$ & $39.60 \mathrm{a}$ & $69.00 \mathrm{a}$ & $2,650.72 \mathrm{~b}$ \\
V14 & $32.92 \mathrm{a}$ & $15.55 \mathrm{a}$ & $0.345 \mathrm{~b}$ & $8.550 \mathrm{~b}$ & $38.36 \mathrm{~b}$ & $74.75 \mathrm{a}$ & $2,506.42 \mathrm{~b}$ \\
V15 & $33.97 \mathrm{a}$ & $15.17 \mathrm{a}$ & $0.433 \mathrm{a}$ & $11.333 \mathrm{a}$ & $38.22 \mathrm{~b}$ & $66.50 \mathrm{~b}$ & $2,609.65 \mathrm{~b}$ \\
V16 & $31.95 \mathrm{~b}$ & $12.10 \mathrm{~b}$ & $0.334 \mathrm{~b}$ & $8.700 \mathrm{~b}$ & $38.68 \mathrm{~b}$ & $62.25 \mathrm{~b}$ & $2,639.30 \mathrm{~b}$ \\
V17 & $31.85 \mathrm{~b}$ & $15.50 \mathrm{a}$ & $0.319 \mathrm{~b}$ & $7.940 \mathrm{~b}$ & $37.52 \mathrm{~b}$ & $69.50 \mathrm{a}$ & $2,547.85 \mathrm{~b}$ \\
V18 & $35.57 \mathrm{a}$ & $8.72 \mathrm{c}$ & $0.209 \mathrm{~b}$ & $6.673 \mathrm{~b}$ & $39.91 \mathrm{a}$ & $66.00 \mathrm{~b}$ & $2,007.50 \mathrm{c}$ \\
V19 & $33.00 \mathrm{a}$ & $8.88 \mathrm{c}$ & $0.246 \mathrm{~b}$ & $8.303 \mathrm{~b}$ & $39.13 \mathrm{a}$ & $76.25 \mathrm{a}$ & $2,104.97 \mathrm{c}$ \\
V20 & $33.22 \mathrm{a}$ & $13.07 \mathrm{~b}$ & $0.258 \mathrm{~b}$ & $7.810 \mathrm{~b}$ & $38.48 \mathrm{~b}$ & $57.75 \mathrm{~b}$ & $2,359.65 \mathrm{~b}$ \\
V21 & $31.94 \mathrm{a}$ & $17.37 \mathrm{a}$ & $0.425 \mathrm{a}$ & $11.097 \mathrm{a}$ & $38.26 \mathrm{~b}$ & $61.75 \mathrm{~b}$ & $3,007.50 \mathrm{a}$ \\
\hline CV (\%) & 4.92 & 22.48 & 26.63 & 15.42 & 2.02 & 11.34 & 11.98 \\
\hline
\end{tabular}

$\mathrm{CV}=$ coefficient of variation. Means followed by the same letter in the column do not differ by the Scott-Knott test at $5 \%$ probability. 
The photosynthetic rates (PR) of the sunflower varieties showed significant differences, forming three groups according to the Scott-Knott test $(5 \%)$. The cultivars of the group with the highest PR had averages of 14.50 to $18.90 \mu \mathrm{mol}$ of $\mathrm{CO}_{2} \mathrm{~m}^{-2} \mathrm{~s}^{-1}$.

The cultivars of the third group (V2, V6, V18 and V19) had the lowest PR averages. These cultivars are in the two groups of lower achene yield, which denotes a correlation between photosynthetic rates and yield potentials, and indicates their low adaptability to the local climate.

The cultivars that had the lowest photosynthetic rates (V2, V6, V18 and V19) were in the group formed by the cultivars with the lowest values of stomatal conductance (STC). This result was also attribute to the low adaptability of these varieties to the local climatic conditions. The correlation between these parameters, confirm the studies of Lisar et al. (2012), who suggested that the decreases in photosynthetic rates are directly affected by the stomata closure, which are verified by the reductions in stomatal conductance.

The cultivars V12, V15, V21, V9, V10, V3, $\mathrm{V} 1, \mathrm{~V} 4, \mathrm{~V} 11, \mathrm{~V} 5$ and $\mathrm{V} 13$ had the highest average transpiration (TR) (9.57 to $11.90 \mathrm{mmol} \mathrm{H}_{2} \mathrm{O} \mathrm{m}^{-2} \mathrm{~s}^{-1}$ ), which were significantly higher than the TR of the other varieties. The transpiration process of sunflower is very important in semiarid environments, since the water deficit may contribute to significant reductions in plant growth and development. According to Castro and Farias (2005), the reduction of water availability for a short period does not cause injury to the cells, but if there is no water replenishment, the plant will not be able to recover overnight, which will affect metabolic processes of the plant. Thus, sunflower plants must have available water to replenish water losses during the transpiration process. Wanderley (2013) studied the sunflower cultivar Embrapa 122-V200 and found an average TR of $5.203 \mathrm{mmol} \mathrm{H}_{2} \mathrm{O} \mathrm{m}^{-2} \mathrm{~s}^{-1}$, which is close to the TR found in the present study (7.813 $\mathrm{mmol} \mathrm{H}_{2} \mathrm{O} \mathrm{m}^{-2} \mathrm{~s}^{-1}$ ) (V6).

The leaf average temperatures (LAT) of the varieties showed significant differences (Table 4). The varieties V6, V2, V18, V13, V11, V5, V1, V4, V8 and V19 had LAT of 39.1 to $40.6{ }^{\circ} \mathrm{C}$, which was significantly higher than the LAT of the other varieties. High leaf temperatures can cause stomata closure, decrease photosynthetic rates, reduce enzymatic activity and even enzymatic denaturation. The varieties V7, V12, V21 and V8 had higher photosynthetic rates and lower LAT, except the variety V8, which had higher LAT than the other varieties. These results explain their greater adaptability and higher yields. Despite the statistical difference, the LAT of V8 was only $0.17{ }^{\circ} \mathrm{C}$ from the temperature range of the second group. According to Backes et al. (2008), edaphoclimatic variations, especially water and thermal availability, relative humidity and luminosity, are factors that strongly affect achene yield. Silva et al. (2013) found a LAT of $35{ }^{\circ} \mathrm{C}$ in sunflower leaves at 110 days after sowing.

The average 1000-achene weight (1000AW) of the varieties showed significant differences, however, the group formed by the cultivars with the highest averages was not necessarily related to the group with the highest yields, indicating that the highest achene yield may be related to the highest number of achenes per capitulum in the region studied. Silva et al. (2007) found an average $1000 \mathrm{AW}$ of only $35.61 \mathrm{~g}$ in the irrigated variety V18. Silva et al (2011) found an average 1000AW of $71.49 \mathrm{~g}$ for the variety Embrapa $122 \mathrm{~V}-2000$, which was close to those found in the present study.

The achene yield (AY) of the varieties had great statistical variability, similar to that found for the CD. The cultivars that presented the highest photosynthetic rates had the highest AY (Table 4), reinforcing a positive correlation between these parameters. Farias Neto et al. (2000) found maximum AY of 4,147 (V10) and 4,066 kg ha (C9302) in irrigated crops of sunflower varieties in the Distrito Federal, Brazil. Andrade et al. (2011), found an AY of only $491.4 \mathrm{~kg} \mathrm{ha}^{-1}$ for the variety V15, in Souza PB. Silva et al. (2007) found a technical efficiency in the production of the irrigated hybrids Helio 250 and Helio 251 in Lavas, State of Minas Gerais, Brazil, with AY of approximately $2,863 \mathrm{~kg} \mathrm{ha}^{-1}$, with a water depth of $130 \%$ of the crop evapotranspiration.

These AY differences in the studied varieties may be related to the irrigation management, crop spacing and their different adaptability to the local edaphoclimatic conditions.

\section{CONCLUSIONS}

The sunflower varieties V7 and V8 reach achene yields above $2,960 \mathrm{~kg} \mathrm{ha}^{-1}$ and have low number of lodged and broken plants, thus, they are good options for crops in the Brazilian semiarid region.

\section{REFERENCES}

ALLEN, R. G. et al. Evapotranspiration del cultivo: guias para la determinación de los requerimientos de agua de los cultivos. Roma: FAO, 2006, 298 p. (Estudio Riego e Drenaje Paper, 56).

ANDRADE, W. C. et al. Desempenho de diferentes cultivares de girassol no perímetro irrigado de São Gonçalo, município de Sousa-PB. Enciclopédia Biosfera, Goiânia, v. 7, n. 12, p. 1-6, 2011. 
BACKES, R. L. et al. Desempenho de cultivares de girassol em duas épocas de plantio de safrinha no planalto norte catarinense. Scientia Agraria, Curitiba, v. 9, n. 1, p. 41-48, 2008.

BISCARO, G. A. et al. Adubação nitrogenada em cobertura no girassol irrigado nas condições de Cassilândia-MS. Ciência e Agrotecnologia, Lavras, v. 32, n. 5, p. 1366-1373, 2008 .

BORGES, B. M. M. N.; LUCAS, F. T.; PAES, J. M. V. Avaliação fenológica de cultivares de girassol (Helianthus annuus, L.) em Uberaba/MG - Safra 2009. Revista Nucleus, Ituverava, v. 10, n. 2, p. 191 $-198,2013$.

CAPONE, A. et al. Efeito de épocas de semeadura de girassol na safrinha, em sucessão à soja no Cerrado Tocantinense. Revista Ceres, Viçosa, v. 59, n. 1, p. 102-109, 2012.

CASTRO, C.; FARIAS, J. R. B. Ecofisiologia do girassol. In: LEITE, R. M. V. B. C.; BRIGHENTI, A. M.; CASTRO, C. (Eds.). Girassol do Brasil. Londrina: Embrapa Soja, 2005. cap. 9, p. 163-218.

CASTRO, C.; OLIVEIRA, F. A. Nutrição e adubação do girassol. In: LEITE, R. M. V. B. C.; BRIGHENTI, A. M.; CASTRO, C. (Eds.). Girassol no Brasil. Londrina: Embrapa Soja, 2005. cap. 13, p. 317-373.

COMPANHIA NACIONAL DE ABASTECIMENTO - CONAB. Acompanhamento da safra brasileira de grãos, v. 7- Safra 2015/16. Disponível em: <http://www.conab.gov.br/ OlalaCMS/uploads/ arquivos/16_02_22_08_52_55_girassol__conjuntura_mensal_-_janeiro_de_2016.pdf $>$. Acesso em: 08 de abr. 2016.

FARIAS NETO, A. L. et al. Avaliação de variedades de girassol nos cerrados do Distrito Federal. Revista Ceres, Viçosa, v. 47, n. 273, p. 469-482, 2000.

FERRARI, R. A.; SOUZA, W. L. Avaliação da estabilidade oxidativa de biodiesel de óleo de girassol com antioxidantes. Química Nova, São Paulo, v. 32, n. 1, p. 106-111, 2009

FERREIRA, A. M. D. R. P. Microclima e desenvolvimento do girassol em condições semiáridas mediterrâneas. 2007. 212 f. Tese (Doutorado em Engenharia Agronómica: Área de Concentração em Engenharia dos Biossistemas) Universidade Técnica de Lisboa, Lisboa, 2007.

FERREIRA, D. F. Sisvar: a guide for its bootstrap procedures in multiple comparisons. Ciência $\mathbf{e}$
Agrotecnologia, Lavras, v. 38, n. 2, p. 109-112, 2014.

GOMES, E. P. et al. Produtividade de grãos, óleo e massa seca de girassol sob diferentes lâminas de irrigação suplementar. Revista Brasileira de Engenharia Agrícola e Ambiental, Campina Grande, v. 16, n. 3, p. 237-246, 2012.

GRILO, E. C. et al. Alpha-tocopherol and gammatocopherol concentration in vegetable oils. Food Science and Technology, Campinas, v. 34, n. 2, p. 379-385, 2014

HARRIS, T. M. et al. Life cycle assessment of sunflower cultivation on abandoned mine land for biodiesel production. Journal of Cleaner Production, Oxford, v. 112, n. 1, p. 182-195, 2016

LISAR, S. Y. S. et al. Water stress in plants: causes, effects and responses. In: RAHMAN, I. M. M. (Ed.). Water Stress. Rijeka: Intech. Publ., 2012, p. 1-14.

MOURA, M. S. B. et al. Clima e água de chuva no Semi-Árido. In: BRITO, L. T. L.; MOURA, M. S. B.; GAMA, G. F. B. (Eds.). Potencialidades da água de chuva no Semi-Árido brasileiro. Petrolina: Embrapa Semi-Árido, 2007. cap. 2, p. 37-59.

NOBRE, R. G. et al. Produção do girassol sob diferentes lâminas com efluentes domésticos e adubação orgânica. Revista Brasileira de Engenharia Agrícola e Ambiental, Campina Grande, v. 14, n. 7, p. 747-754, 2010.

OLIVEIRA, R. L. et al. Commercial cuts and chemical and sensory attributes of meat from crossbred Boer goats fed sunflower cake-based diets. Animal Science Journal, Tokyo, v. 86, n. 5, p. $557-$ 562,2015

PORTO, W. S.; CARVALHO, C. G. P.; PINTO, R. J. B. Adaptabilidade e estabilidade como critérios para seleção de genótipos de girassol. Pesquisa Agropecuária Brasileira, Brasília. v. 42, n. 4, p. 491-499, 2007.

REGO, G. M.; POSSAMAI, E. Efeito do sombreamento sobre o teor de clorofila e crescimento inicial do jequitibá-rosa. Boletim de Pesquisa Florestal, Colombo, n. 53, p. 179-194, 2006.

SHARMA, D. K. et al. Wheat cultivars selected for high $\mathrm{F} v / \mathrm{F} \mathrm{m}$ under heat stress maintain high photosynthesis, total chlorophyll, stomatal conductance, transpiration and dry matter. Physiologia Plantarum, Copenhagen, v. 153, n. 2, p. 284-298, 2015. 
SILVA, A. R. A. et al. Desempenho de cultivares de girassol sob diferentes lâminas de irrigação no Vale do Curu, CE. Revista Ciência Agronômica, Fortaleza, v. 42, n. 1, p. 57-64, 2011.

SILVA, A. R. A. et al. Trocas gasosas em plantas de girassol submetidas à deficiência hídrica em diferentes estádios fenológicos. Revista Ciência Agronômica, Fortaleza, v. 44, n. 1, p. 86-93, 2013.

SILVA, M. L. O. et al. Crescimento e produtividade do girassol cultivado na entressafra com diferentes lâminas de água. Revista Brasileira de Engenharia Agrícola e Ambiental, Campina Grande, v. 11, n. 5, p. 482-488, 2007.

VOGT, G. A.; BALBINOT JÚNIOR, A. A.; SOUZA, A. M. Divergência genética entre cultivares de girassol no Planalto Norte Catarinenses. Scientia Agraria, Curitiba, v. 11, n. 4, p. 307-315, 2010.

WANDERLEY, J. A. C. Morfofisiologia e produção do girassol sob técnicas de captação de água "in situ" e adubação orgânica. 2013. 76 f. Dissertação (Mestrado em Engenharia Agrícola: Área de Concentração em Irrigação e Drenagem) Universidade Federal Campina Grande, Campina Grande, 2013.

ZHENG, T. C. et al. Genetic gains in grain yield, net photosynthesis and stomatal conductance achieved in Henan Province of China between 1981 and 2008. Field Crops Research, Amsterdam, v. 122, n. 3, p. 225-233, 2011. 